\title{
Penerapan Sistem Pakar Untuk Diagnosa Autis Dengan Metode Forward Chaining
}

\author{
Rizal Rachman \\ STMIK Nusa Mandiri \\ Jl. Damai No. 8 ( Margasatwa) Pasar Minggu Jakarta Selatan \\ e-mail: rizalkhaizuran@gmail.com
}

\begin{abstract}
Abstrak
Sistem yang menggunakan pengetahuan manusia, dimana pengetahuan tersebut dimasukkan ke dalam sebuah komputer, dan kemudian digunakan untuk menyelesaikan masalah-masalah yang biasanya membutuhkan kepakaran atau keahlian manusia. Dalam kasus ini, sistem pakar digunakan untuk Diagnosa Autisme Di SLB N Cileunyi, Autisme merupakan gangguan perkembangan mental pada anak yang menyebabkan seorang anak sulit untuk berinteraksi social. Secara umum, gejala autisme terdeteksi pada usia awal perkembangan anak sebelum mencapai tiga tahun. Gejala dan tingkat keparahan autisme juga cenderung bervariasi pada tiap penyandang. Diagnosa autisme biasanya dilakukan oleh seorang pakar/ahli dibidang tumbuh kembang anak, namun sebenarnya orang tua juga dapat melakukan diagnosa awal kemungkinan autisme pada anak dengan melakukan pengamatan perilaku anak dalam kesehariannya terutama dari cara berkomunikasi, berinteraksi sosial dengan anak sebayanya, dan kemampuan berimajinasi pada anak. Didalam penerapan sistem pakar ini dibantu dengan menggunakan metode forward chaining. Metode Forward Chaining digunakan sebagai teknik penalaran dari Knowledge Respresentation Pakar, keluaran pada sistem berupa ada tidaknya kemungkinan autisme pada seorang anak berdasarkan gejala yang diberikan kepada sistem.
\end{abstract}

\section{Kata Kunci: Sistem pakar, Autisme, Diagnosa, Forward Chaining}

\begin{abstract}
Systems that use human knowledge, where knowledge is incorporated into a computer, and then used to solve problems that usually require expertise or human skills. In this case, the expert system is used for Autism Diagnosis In SLB N Cileunyi, Autism is a mental development disorder in children that causes a child difficult to interact socially. In general, symptoms of autism are detected in early child development before reaching three years. The symptoms and severity of autism also tend to vary with each person. Diagnosis of autism is usually done by an expert / expert in the field of child growth, but actually parents can also make early diagnosis of possible autism in children by observing children's behavior in daily life, especially from how to communicate, social interaction with children sebayanya, and ability to imagine in children. In the application of this expert system is assisted by using forward chaining method. Forward Chaining method is used as a reasoning technique of Knowledge Respresentation Experts, the output on the system of the presence or absence of the possibility of autism in a child based on the symptoms given to the system.
\end{abstract}

\section{Key Word: Expert System, Autism, Diagnosis, Forward Chaining}

\section{Pendahuluan}

Seiring dengan berkembangannya jaman, kebutuhan manusia untuk mengakses informasi secara cepat juga meningkat. Untuk memenuhi kebutuhan tersebut, saat ini teknologi sistem informasi telah muncul dengan berbagai inovasi baru yang secara terus menerus mengalami perubahan yang berarti. Kehadiran teknologi komputer dengan kekuatan prosesnya telah memungkinkan pengembangan sistem informasi ke berbagai bidang. Dengan memanfaatkan teknologi komputer, didapat manfaat berupa kemudahan menyimpan, mengorganisasi dan melakukan pengambilan terhadap berbagai data (Ariyani, 2012).

Autisme merupakan gangguan perkembangan pada anak yang menyebabkan seorang anak sulit untuk berinteraksi sosial. Diagnosa autisme 
biasanya dilakukan oleh seorang pakar atau ahli dibidang tumbuh kembang anak, namun sebenarnya orang tua juga dapat melakukan diagnosa awal kemungkinan gangguan autisme pada anak usia dini dengan melakukan pengamatan perilaku anak dalam kehidupan sehari-hari, terutama didalam cara berkomunikasi, berinteraksi sosial dengan anak-anak sebayanya, dan kemampuan berimajinasi (Peeters, 2008).

Mereka memiliki gangguan perkembangan fungsi otak yang mencakup bidang sosial, komunikasi verbal (bahasa) dan non-verbal, imajinasi, fleksibilitas, lingkup minat, kognisi dan perhatian. Gangguan autisme pada anak-anak timbul sebelum usia tiga tahun, tetapi ada pula yang sudah mengalami gangguan tersebut sejak lahir. Ciri-ciri autisme yang tampak adalah anak sangat pendiam, jarang menunjukan senyum sosial, menjadi tegang apabila diegendong, senang menyendiri dan bersikap dingin sejak kecil atau bayi, misalnya dengan tidak memberi respon (tersenyum, dan sebagainya), bila tidak dibujuk, diberi makanan dan sebagainya, serta seperti tidak menaruh perhatian terhadap lingkungan sekitar, tidak mau atau sangat sedikit berbicara, hanya mau mengatakan ya atau tidak, atau ucapanucapan lain yang tidak jelas, tidak suka dengan stimulasi pendengaran (mendengarkan suara ataupun menangis), senang melakukan stimulasi diri, memukulmukul kepala atau gerakan-gerakan aneh lain, namun kadang-kadang terampil memanipulasikan objek (Winiarti, 2012).

Secara teori sistem pakar adalah sistem berbasis komputer yang menggunakan pengetahuan, fakta, dan teknik penalaran dalam memecahkan masalah yang biasanya hanya dapat dipecahkan oleh seorang pakar dalam bidangnya (Kusumadewi, 2008), Pada dasarnya sistem pakar diterapkan untuk mendukung aktifitas pemecahan masalah. (Lestari, 2012), Pengembangan sistem pakar dari awal hingga menghasilkan solusi akhir melibatkan peran serta 4 kelompok (Rosnelly, 2012) yaitu pakar, pengembangan pengetahuan, pembangunan sistem dan pemakai

Forward Chaining Menurut (Nidhra, 2015) adalah metode pencarian / penarikan kesimpulan yang berdasarkan pada fakta yang ada menuju ke kesimpulan, penelusuran dimulai dari fakta yang ada lalu bergerak maju melalui premis-premis untuk menuju ke kesimpulan / bottom up reasoning. Penelitian yang dilakukan oleh (Qoriani, 2015), "Diagnosa Gangguan Autisme Pada Anak Berbasis Perangkat Bergerak Android" untuk mendeteksi autisme secara dini sehingga khususnya para masyarakat awam dan para orang tua akan adanya gangguan autism pada anak , sehingga informasi tersebut dapat ditindak lanjuti lebih dini. Dengan Deteksi dini gangguan autism pada anak, maka dapat dilakukan penanganan yang tepat dan intensif, sehingga anak dapat berkembang dan tumbuh dengan baik. Tindak lanjut tersebut sebagai upaya untuk pengetahuan masyarakat awam/ orang tua agar lebih lebih tahu, lebih cermat, perhatian dan waspada terhadap tumbuh kembang anak. Sistem pakar yang dibangun adalah merupakan suatu pustaka dari dokter spesialis dan kondisi yang digunakan untuk mengambil penghitungan kesimpulan dari gejala dan kategori gangguan anak. Dalam proses penghitungannya metode Inferensi (forward chaining) dengan Probabilitas Klasik. Parameter yang dipergunakan dalam diagnosa adalah usia anak dan Gejala Yang Diinputkan. Kesimpulan aplikasi ini berupa Jenis gangguan yang diderita anak, solusi penanganan berupa obat dan terapi sesuai dengan usia dan jenis gangguan pada anak.

Penelitian yang dilakukan oleh (Aprilia, 2014), "Sistem Pakar Diagnosa Autisme Pada Anak" Seiring dengan kemajuan pesat teknologi komputer saat ini, perkembangan bidang medis dan psikiatris juga mengalami kemajuan yang pesat. Kemajuan bidang medis dan psikiatris akan semakin lengkap jika dapat didukung perkembangan teknologi komputer, terutama teknologi perangkat lunaknya.

Penelitian yang dilakukan oleh (Widians, 2008), membangun aplikasi sistem pakar untuk mendiagnosa gangguan autis pada anak. Metode yang digunakan dalam penelitian di atas adalah DSM IV. Diagnostic and Statistical Manual (DSM IV) merupakan aturan klinis yang dapat digunakan untuk mendiagnosa autisme.

\section{Metode Penelitian}

Metode yang digunakan untuk melihat kondisi anak apakah mempunyai autisme atau tidak, kita menggunakan sistem pakar metode Forward Chaining.

Forward chaining melakukan pencarian dari suatu masalah kepada solusinya. Jika klausa premis sesuai dengan 
situasi, maka proses akan memeberikan kesimpulan.

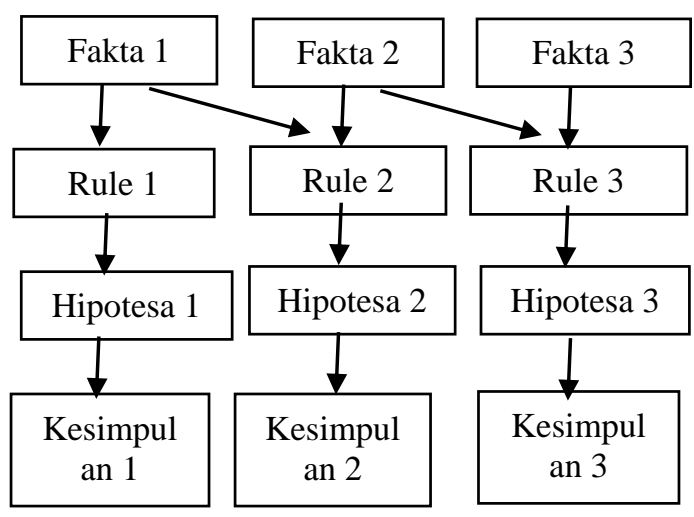

Sumber : (Verina, 2015)

Gambar 1.

Gambaran Kerja Forward Chaining

Maka berdasarkan metode ini langkahlangkah yang diambil:

$$
\begin{aligned}
& \text { R1 : IF A and C, THEN B } \\
& \text { R2 : IF D and C, THEN F } \\
& \text { R3 : IF B and E, THEN F } \\
& \text { R4 : IF B, THEN C } \\
& \text { R5 : IF F, THEN G }
\end{aligned}
$$

\section{Hasil dan Pembahasan}

Adapun tahapan pengumpulan data adalah sebagai berikut :

1. Pada Tahapan ini penulis melakukan pencarian, pembelajaran dari berbagai macam literature dan dokumen yang menunjang pengerjaan tugas akhir ini, khususnya yang berkaitan dengang aplikasi seistem pakar untuk mendiagnosa gangguan autisme pada anak usia dini.

2. Dalam tahap akuisisi pengetahuan yaitu berusaha menyerap pengetahuan untk selanjutnya di transfer kedalam basis data. Pengetahuan tersebut diperoleh dari pakar, kemudian dilengkai dengan buku-buku, basis data, laporan penelitian dan pengalaman pemakai.

3. Melakukan pengamatan ke berbagai website dan jurnal yang menyediakan informasi yang relevan mengenai permasalahan dalam pembuatan sistem ini.

\section{Objek Pakar}

1. Ibu Drs. Nepy Suwastika adalah seorang pakar Autisme beliau menjabat sebagai Kepala Satuan di SLB Negeri Cileunyi dan sudah berpengalaman kurang lebih 23(dua puluh tiga) tahun dalam bidangnya.

2. Bapak Drs. Iwan Rizwan adalah seorang guru Autisme di SLB Negeri Cileunyi beliau menjabat sebagai KAUR Humas di SLB Negeri Cileunyi dan sudah berpengalaman kurang lebih 12(dua belas) tahun di bidang nya

3. Ibu Momi Mahdaniar, M.Pd adalah seorang guru di SLB Negeri Cileunyi beliau menjabat sebagai guru Autisme di SLB Negeri Cileunyi dan sudah berpengalan kurang lebih 10 (sepuluh) tahun di bidang nya.

Tabel 1

\section{Hasil Wawancara}

Nama

Jabatan

Tanda Tangan

\section{Hasil Wawancara}

\begin{tabular}{|c|l|c|c|}
\hline \multirow{2}{*}{ No } & \multicolumn{1}{|c|}{ Pertanyaan } & \multicolumn{2}{c|}{ Jawaban } \\
\cline { 3 - 4 } & & Ya & Tidak \\
\hline 1 & $\begin{array}{l}\text { Konsentrasi Mudah } \\
\text { Teralihkan }\end{array}$ & & \\
\hline 2 & Tidak Bisa Diam & & \\
\hline 3 & Banyak Bicara & & \\
\hline 4 & Sering Kacau & & \\
\hline 5 & $\begin{array}{l}\text { Sulit Mengikuti } \\
\text { Aturan }\end{array}$ & & \\
\hline 6 & Tidak Sabar & & \\
\hline 7 & Suka Gelisah & & \\
\hline 8 & Sulit Membaca & & \\
\hline 9 & $\begin{array}{l}\text { Lambat dalam } \\
\text { Menulis }\end{array}$ & & \\
\hline 10 & $\begin{array}{l}\text { Tidak Bisa Fokus } \\
\text { Untuk satu Hal }\end{array}$ & & \\
\hline
\end{tabular}




\begin{tabular}{|c|c|}
\hline 11 & $\begin{array}{l}\text { Masih tetap } \\
\text { kesulitan dalam } \\
\text { berpakaian }\end{array}$ \\
\hline 12 & $\begin{array}{l}\text { Sulit mengingat } \\
\text { nama atau sebuah } \\
\text { objek }\end{array}$ \\
\hline 13 & Percaya diri rendah \\
\hline 14 & $\begin{array}{l}\text { Sulit dalam } \\
\text { berkembang }\end{array}$ \\
\hline 15 & $\begin{array}{l}\text { Kontak mata sangat } \\
\text { kurang }\end{array}$ \\
\hline 16 & $\begin{array}{l}\text { Ekspresi muka } \\
\text { kurang hidup }\end{array}$ \\
\hline 17 & $\begin{array}{l}\text { Gerak gerik kurang } \\
\text { tertuju }\end{array}$ \\
\hline 18 & $\begin{array}{l}\text { Menolak untuk } \\
\text { dipeluk }\end{array}$ \\
\hline 19 & $\begin{array}{l}\text { Tidak menengok } \\
\text { ketika dipeluk }\end{array}$ \\
\hline 20 & $\begin{array}{l}\text { Menangis dan } \\
\text { tertawa tanpa } \\
\text { sebab }\end{array}$ \\
\hline 21 & $\begin{array}{l}\text { Tidak tertarik pada } \\
\text { mainan }\end{array}$ \\
\hline 22 & $\begin{array}{l}\text { Terlambat } \\
\text { berbicara }\end{array}$ \\
\hline 23 & $\begin{array}{l}\text { Gangguan } \\
\text { Pendengaran }\end{array}$ \\
\hline 24 & $\begin{array}{l}\text { Keterbelakangan } \\
\text { Mental }\end{array}$ \\
\hline 25 & $\begin{array}{l}\text { Pasif dalam } \\
\text { berkomunikasi }\end{array}$ \\
\hline 26 & Sulit untuk mengeja \\
\hline 27 & $\begin{array}{l}\text { Kata-kata yang } \\
\text { diucapkan tidak } \\
\text { jelas }\end{array}$ \\
\hline
\end{tabular}

\section{Basis Pengetahuan}

Basis pengetahuan mengandung pengetahuan untuk pemahaman formulasi dan penyelesaian masalah, dengan komponen sistem pakar yang disusun atas dua elemen dasar yaitu fakta dan aturan. Fakta merupakan informasi tentang obyek dalam area permasalahan tertentu, seperti gejala-gejala yang telah dialami. Sedangkan atuaran merupakan informasi tentang cara bagaimana memperoleh fakta baru dari yang telah diketahui.

Dalam basis pengetahuan, data gejala dan gangguan autism diperoleh dari pakar yang di bagi menjadi 4 bagian berdasarkan usia anak, antara lain sebagai berikut:

1. Usia 2 bulan sampai 1 tahun yang terdiri dari 13 gejala dan 5 gangguan

2. Usia 1 tahun sampai 2 tahun yang terdiri dari 11 gejala dan 4 gangguan

3. Usia 2 tahun sampai 3 tahun yang terdiri dari 21 gejala dan 4 gangguan

4. Usia 3 tahun sampai 5 tahun yang terdiri dari 23 gejala dan 7 gangguan

Dari usia yang berbeda dan gangguan yang sama akan menampilkan terapi penanganan yang berbeda berdasar usia anak yang menderita gangguan autism. Setelah basis pengetahuan diketahui, maka selanjutnya dilakukan tahapan penelusuran data yang berupa pohon keputusan pakar

\section{Tabel Pakar}

Analisa data yang akan dilakukan adalah autisme, dimana autisme ini proses perkembangan anak dalam masa usia dibawah 10 tahun. autisme dalam hal ini dapat dibagi menjadi 4 jenis antara lain :

1. Gangguan Pemusatan Perhatian (Hyperactive)

2. Gangguan Belajar (Learning Disabilities)

3. Gangguan Autisme

4. Gangguan Bicara (Articulasi)

Untuk mengetahui apakah seorang anak dikatakan mengidap autisme terlebih dahulu kita mengetahui apa yang sering menjadi keluhan atau yang dialami anak tersebut, keluhan itu akan dijadikan sebagai salah satu gejala, adapun gejala-gejala umum dari setiap autisme antara lain : Untuk lebih jelasnya penggunaan gejala sebagai inputan dalam sistem, maka setiap gelaja dilambangkan dengan kode gejala, Dari tabel pakar dibawah, sistem dapat memberikan informasi mengenai autisme, jika gejala yang dialami anak tersebut sesuai dengan yang diinput, maka rule yang dapat digunakan untuk menganalisa suatu gangguan autisme. 
Tabel 2

Tabel Pakar Autisme

\begin{tabular}{|c|c|c|}
\hline No & Gejala & $\begin{array}{l}\text { Kode } \\
\text { Gejala }\end{array}$ \\
\hline 1 & $\begin{array}{l}\text { Konsentrasi Mudah } \\
\text { Teralihkan }\end{array}$ & GP1 \\
\hline 2 & Tidak Bisa Diam & GP2 \\
\hline 3 & Banyak Bicara & GP3 \\
\hline 4 & Sering Kacau & GP4 \\
\hline 5 & Sulit Mengikuti Aturan & GP5 \\
\hline 6 & Tidak Sabar & GP6 \\
\hline 7 & Suka Gelisah & GP7 \\
\hline 8 & Sulit Membaca & GP8 \\
\hline 9 & Lambat dalam Menulis & GP9 \\
\hline 10 & $\begin{array}{l}\text { Tidak Bisa Fokus Untuk } \\
\text { satu Hal }\end{array}$ & GP10 \\
\hline 11 & $\begin{array}{l}\text { Masih tetap kesulitan } \\
\text { dalam berpakaian }\end{array}$ & GP11 \\
\hline 12 & $\begin{array}{l}\text { Sulit mengingat nama } \\
\text { atau sebuah objek }\end{array}$ & GP12 \\
\hline 13 & Percaya diri rendah & GP13 \\
\hline 14 & Sulit dalam berkembang & GP14 \\
\hline 15 & $\begin{array}{l}\text { Kontak mata sangat } \\
\text { kurang }\end{array}$ & GP15 \\
\hline 16 & $\begin{array}{l}\text { Ekspresi muka kurang } \\
\text { hidup }\end{array}$ & GP16 \\
\hline 17 & $\begin{array}{l}\text { Gerak gerik kurang } \\
\text { tertuju }\end{array}$ & GP17 \\
\hline 18 & Menolak untuk dipeluk & GP18 \\
\hline 19 & $\begin{array}{l}\text { Tidak menengok ketika } \\
\text { dipeluk }\end{array}$ & GP19 \\
\hline 20 & $\begin{array}{l}\text { Menangis dan tertawa } \\
\text { tanpa sebab }\end{array}$ & GP20 \\
\hline 21 & $\begin{array}{l}\text { Tidak tertarik pada } \\
\text { mainan }\end{array}$ & GP21 \\
\hline 22 & Terlambat berbicara & GP22 \\
\hline
\end{tabular}

\begin{tabular}{|l|l|l|}
23 & Gangguan Pendengaran & GP23 \\
\hline 24 & Keterbelakangan Mental & GP24 \\
\hline 25 & $\begin{array}{l}\text { Pasif dalam } \\
\text { berkomunikasi }\end{array}$ & GP25 \\
\hline 26 & Sulit untuk mengeja & GP26 \\
\hline 27 & $\begin{array}{l}\text { Kata-kata yang } \\
\text { diucapkan tidak jelas }\end{array}$ & GP27 \\
\hline
\end{tabular}

Rule-rule pada pakar

1. Rule 1 : If jenis gejala GP1 AND GP2 AND GP3 AND GP4 AND GP5 AND GP6 AND GP7 Then Gangguan pemusatan perhatian (Hyperactive).

2. Rule 2 : If Jenis gejala GP8 AND GP9 AND GP10 AND GP11 AND GP12 AND GP13 AND GP14 Then Gangguan Belajar (Learning disabilities).

3. Rule 3 : If Jenis gangguan GP15 AND GP16 AND GP17 AND GP18 AND GP19 AND GP20 AND GP21 Then Autisme.

4. Rule 4 : If Jenis gangguan GP22 AND GP23 AND GP24 AND GP25 AND GP26 AND GP27 Then Gangguan bicara (Speech disorder).

Dari alur, rule dan tabel keputusan diatas, maka dapat dikonversikan menjadi kaidah produksi. Kaidah produksi dibentuk dari pengubahan tabel keputusan. Pembuatan suatu kaidah dilakukan dengan beberapa tahapan.

Berikut ini merupakan bentuk pengkonversian tabel keputusan menjadi kaidah produksi :

1. IF (Konsentrasi anak Mudah teralihkan AND Tidak bisa diam AND banyak bicara AND sering kacau AND sulit mengikuti aturan AND tidak sabaran AND suka gelisah) Then Gangguan Pemusatan Perhatian (Hyperactive).

2. IF (Konsestrasi anak Mudah teralihkan AND Sulit membaca dan mengeja AND Sering tertukar huruf dan angka AND percaya diri rendah 
AND Masih tetap kesulitan dalam berpakaian AND Sulit mengingat nama atau sebuah obyek AND sulit dalam berhitung) Then gangguan Belajar (learning disabilities)

3. IF (kontak mata sangat kurang AND ekspresi muka kurangi hidup AND gerak gerik kurang tertuju AND menolak untuk dipeluk AND tidak menengok jika dipeluk AND menangis dan tertawa tanpa sebab AND tidak tertarik pada mainan )Then Gangguan Autisme.

4. IF (terlambat bicara AND mengalami Gangguan pendengaran AND Keterbelakangan mental AND pasif dalam berkomunikasi AND sulit untuk mengeja AND kata-kata yang diucapkan tidak jelas) Then gangguan bicara (Speech disorder).

\section{Pohon keputusan Pakar}

Secara umum terdapat dua pendekatan yang digunakan dalam mekanisme inferensi untuk pengujian aturan yaitu pelacakan kebelakang (backward chaining) dan pelacakan kedepan (forward chaining). Dalam pelacakan ke belakang adalah pendekatan yang dimotori tujuan (goal- driven), pendekatan ini pelacakan dimulai dari tujuan dan selanjutnya dicari aturan-aturan yang memiliki tujuan tersebut dan dicari kesimpulannya (pembuktian). Sedangkan pelacakan ke depan merupakan pendekatan yang dimotori oleh data (datadriven), pendekatan ini pelacakan dimulai dari informasi masukan, dan selanjutnya mencoba menggambarkan kesimpulan. Seperti pohon keputusan dibawah ini, dimana pohon keputusan dirancang sesuai gejala per gangguan.

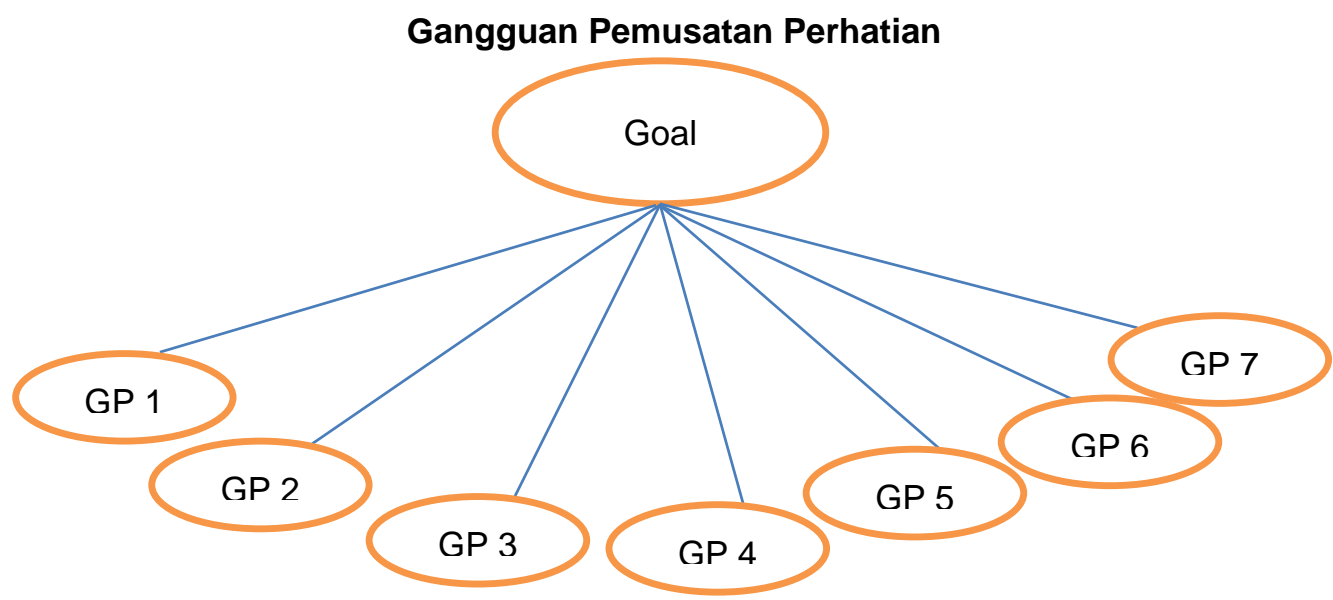

Gambar 2. Pohon keputusan untuk gangguan pemusatan perhatian

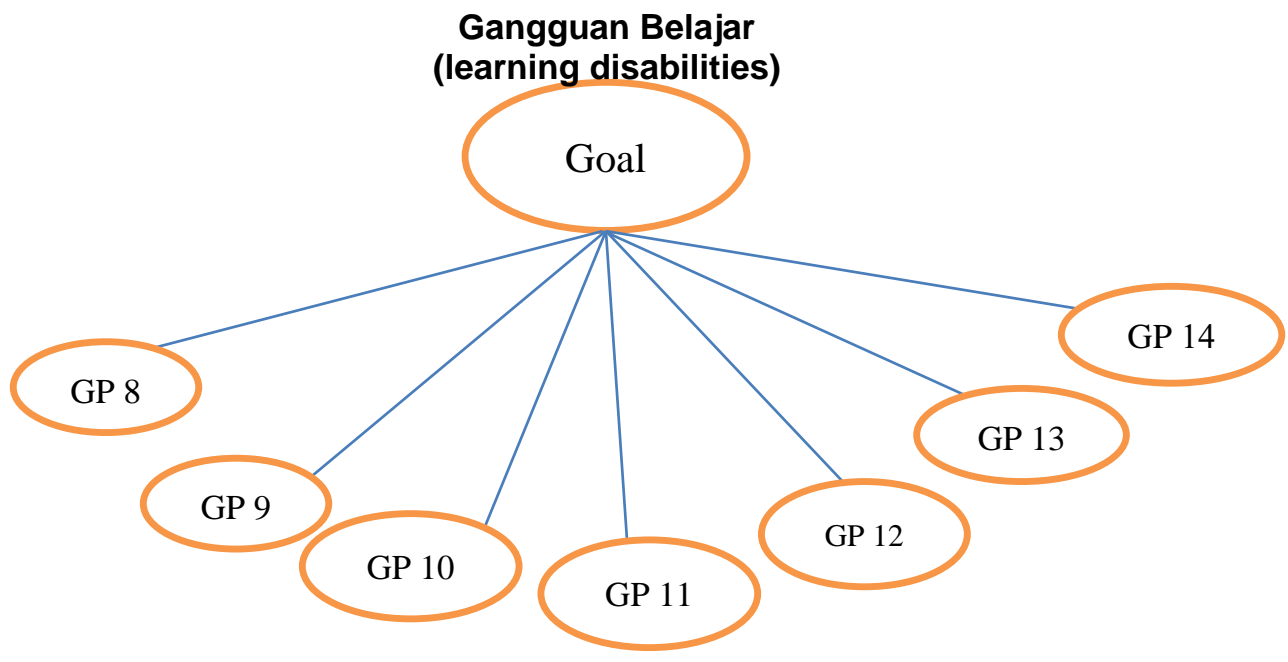

Gambar 3. Pohon keputusan untuk gangguan belajar Gangguan Autisme 


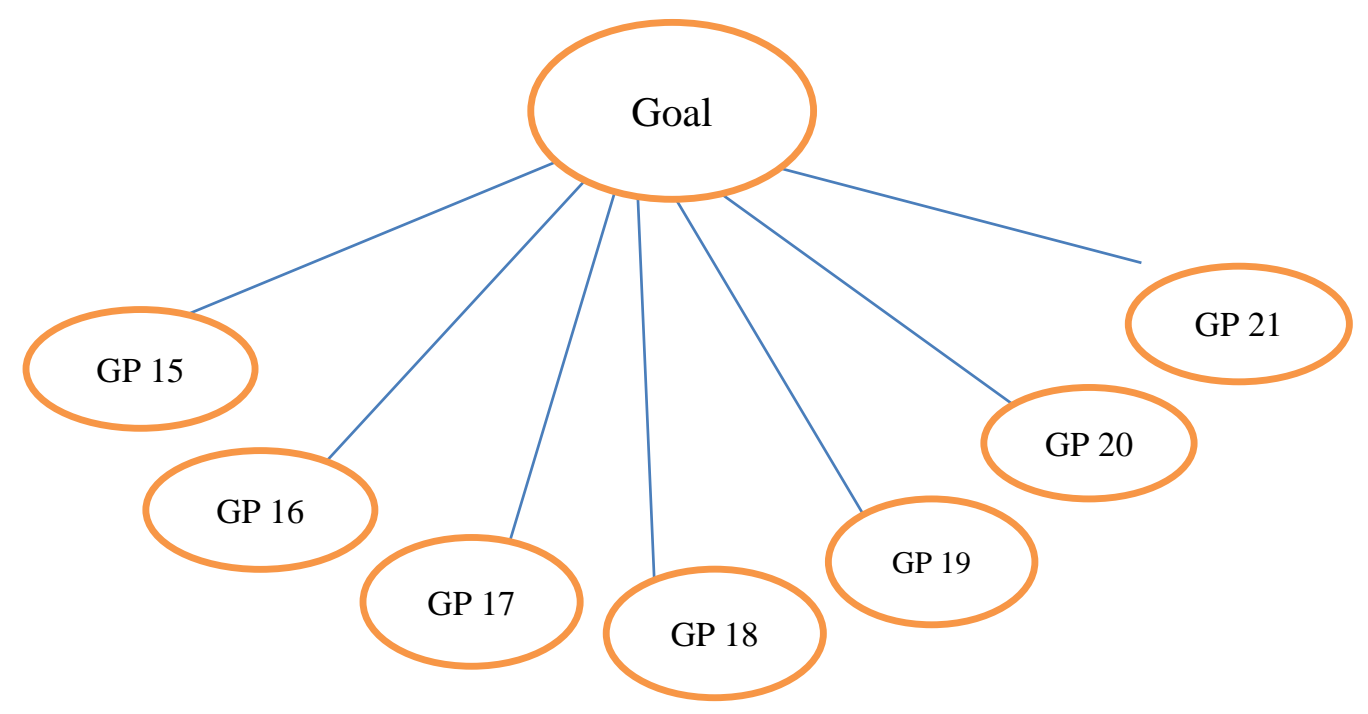

Gambar 4.

Pohon keputusan untuk gangguan autisme

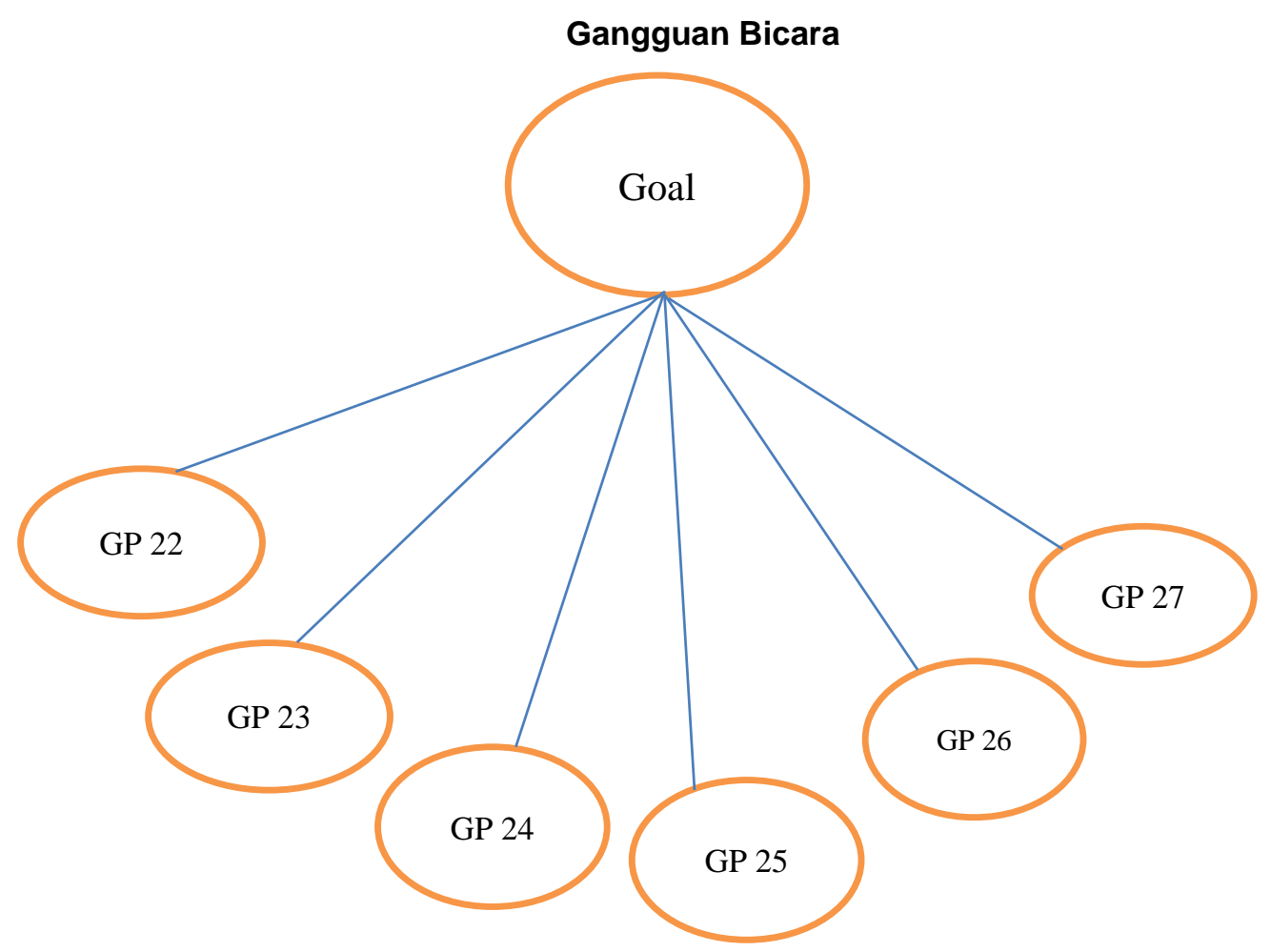

Gambar 5.

Pohon keputusan untuk gangguan bicara 


\section{Implementasi}

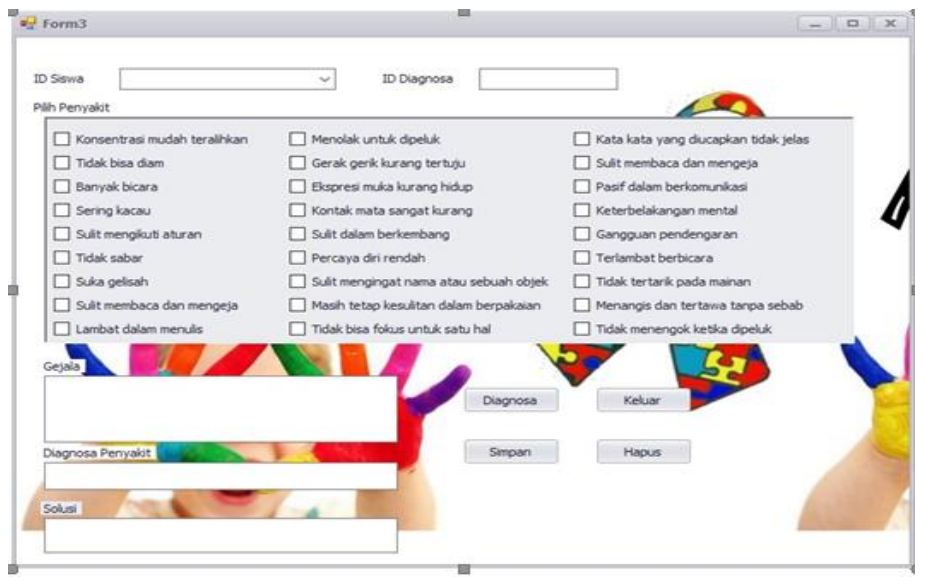

\section{Kesimpulan}

Berdasarkan uraian yang telah dibahas mengenai desktop expert system diagnosa autisme, maka dapat ditarik beberapa kesimpulan sebagai berikut: Menambah pengetahuan tentang jenis-jenis autisme dan gejalanya, Menambah wawasan para orang tua untuk mengetahui lebih awal gangguan autisme pada anakanak mereka sejak usia dini dan Memberikan Solusi dalam menangani gangguan autisme kepada masyarakat, baik para orang tua, guru dan pengasuh

Pembuatan aplikasi desktop expert system diagnosa autisme ini masih belum sepenuhnya sempurna, masih terdapat beberapa kekurangan, maka dapat diusulkan beberapa saran guna menunjang penelitian berikutnya, diantaranya Desktop Expert System Diagnosa Autisme perlu dikembangkan menggunakan model inferensi lain atau menggunakan algoritma lain guna mendapatkan hasil diagnosa dengan tingkat akurasi yang lebih tinggi dari model inferensi Forward Chaining, Desktop Expert System yang dirancang ini akan menjadi lebih sempurna apabila basis pengetahuan yang ada terus diperkaya dengan mengumpulkan data. Dan Informasi yang tidak hanya dari pakar dan studi literature saja, akan tetapi dari dunia pakar yang saat ini terus berkembang.

\section{Referensi}

Aprilia. (2014). Sistem Pakar Diagnosa Autisme pada Anak. Jurnal Rekursif, Vol. 2, No. 2.

Ariyani. (2012). Sistem Informasi Akademik. Salatiga: Universitas Kristen Satya.

Kusumadewi. (2008). Arifical Intelegence ( Teknik dan Aplikasinya ). Yogyakarta: Graha IImu.

Lestari. (2012). Definisi Sistem Pakar. Malang: Arsip Teknik Infromatika, UMMI.

Nidhra. (2015). Black Box and White Box Testing Techniques. International Journal of Embedded System And Applications ( IJESA ), Vol. 2, No. 2.

Peeters. (2008). Panduan Autisme Terlengkap. Jakarta: Dian Rakyat.

Qoriani. (2015). Diagnosa Gangguan Autisme pada Anak Berbasis Perangkat Bergerak. Jurnal LINK, Vol. 23, No. 2, September 2015.

Rosnelly. (2012). Sistem Pakar Konsep dan Teori. Yogyakarta: CV. Andi Offset.

Verina, W. (2015). Penerapan Metode Forward Chaining untuk mendeteksi penyakit THT. Jatisi Vol. 1 No. 2 Maret 2015, 123.

Widians. (2008). Sistem Pendiagnosa Gangguan Autis pada Anak. Tesis S2 IImu Komputer Universitas Gadjah Mada, Yogyakarta.

Winiarti. (2012). Pemanfaatan Teorema Bayes dalam Penentuan Penyakit THT. JIFO, Hal. 287. 